Al-Azhar Bull. Sci. Vol. 19, No. 1 (June.): pp. 43-58, 2008.

\title{
PURIFICATION AND EXTRACTION OF POLYSACCHARIDE SPECIFIC OF STREPTOCOCCUS PYOGENES OF GROUP A FIXING ON LATEX PARTICLES
}

\author{
AHMED. I. ATIA, *HUSSEIN M . EL-KABBANI \\ Natural Products Dept. \& *Health Radiation Research Dept., National Center for \\ Radiation Research and Technology, Atomic Energy Authority, Cairo, Egypt.
}

\begin{abstract}
The Streptococci are widely distributed in nature and frequently form part of the normal human flora which are members. Approximately 5-15\% of humans carry Streptococcus pyogenes. Cytoplasmic membrane has antigens similar to those of human cardiac and heart valve fibroblasts. Patients may also develop immune- mediated such as acute rheumatic fever , skin infections and endocarditis. S. pyogenes evolved an enzyme that specifically targets IgG use as biochemical reactions, and serologic specificity. Serologic grouping is based on antigenic differences in cell wall carbohydrates (groupA). A technique for detection of antibodies against $\boldsymbol{S}$. pyogens group antigen / type antigens is being devised as one of the procedures possibly useable in prevention of infections and manufacturers in development of diagnostic and identification tools. Method used for detection of antibodies ( latex agglutination ) are being standardised with antibody levels has been introduced. The detection of antibodies induced by conjugated is under development for antibiotic resistance of Streptococcus pyogenes prepared and provided freeze-dried reference type cultures of Streptococci. The stability of the obtained component subjected at $4{ }^{\circ} \mathrm{C}$ and $37{ }^{\circ} \mathrm{C}$ over one period to reveal several groups of serum representing healthy population $(\mathrm{N}=20)$ and patients ( $\mathrm{N}=40$ ) as a significant correlation for the diagnostic of acute rheumatic arthritis .We have shown that the total amount of specific antibodies does not necessary correlate with the level of neutralizing antibodies, and antibody quality might be clinically more important than antibody quantity
\end{abstract}

\section{Introduction}

Streptococcus pyogenes is an important human bacterial pathogen that causes a variety of diseases Beall, (2002).The survival of S. pyogenes depends on its ability to avoid the various actions of the human immune system. Immunoglobulin $\mathrm{G}$ ( $\operatorname{IgG}$ ) plays a key role in the immune defense by specifically recognizing invading microorganisms. Cunningham, (2000).

Microbiological diagnosis and identification of agents are based on a wide range of characteristics recommended. Streptococci are Gram-positive, facultative anaerobes, require enriched media (blood agar). Group A Streptococci have a hyaluronic acid capsule., hemolysis,. The preliminary species identification by general test and technique ( latex agglutination method ) were detected of the group 
antigen from isolated colonies and clinical material including swabs Lei (2001). The species that contain group antigens of more sero groups are identified by biochemical and physiological tests which allowing the detection of constitutive enzymes.For the reasons of standardisation the primarily uses commercial diagnostic kits with high identification Facklam (2002).

In order to persist, pathogenic bacteria have to find ways to avoid recognition by immunoglobulins. S. pyogenes has evolved a specific enzyme to deal with opsonizing IgG antibodies. This enzyme is a secreted proteinase that specifically cleaves the heavy chain of $\operatorname{IgG}$, and is the sole substrate in plasma samples, due to its early and sustained expression during growth and its highly specific proteolytic activity.Agniswamy,(2004).

Other analyses of antistreptococcal antibodies, however, have shown that the total amount of specific antibodies does not necessary correlate with the level of neutralizing antibodies, and antibody quality might be clinically more important than antibody quantity Norrby-Teglund,(1996). The fact that $S$. pyogenes has evolved an enzyme that specifically targets $\mathrm{IgG}$, the presence of neutralizing antibodies correlates with manifestations of $S$. pyogenes infection or affects the severity of $S$. pyogenes-induced disease. Sriprakash, (2002).

\section{Patient and Methods}

- Fourty patients with ages ranged from 1 to up 12 years from Abu el rich hospital clinic .

- Twenty Healthy normal subjets with matched ages and sex as controls.

- Type-specific precipitation sera against all described polysaccharide and protein antigens are prepared for $S$. pyogens typing identified by the Quellung technique with 164 sera (polyvalent, group, type, factor) provided by the Statens Seruminstitut, Denmark .

- ELISA technique: Microtiter plates were coated with enzymatically inactive Lukomski, (2000).Nonpolar inactivation of the hypervariable streptococcal inhibitor of complement gene in serotype M1 Streptococcus pyogenes significantly decreases mouse mucosal colonization. Infect. Immun. at $0.4 \mu \mathrm{g} / \mathrm{ml}$ in coating buffer (0.05 $\mathrm{M} \mathrm{NaHCO}_{3}$, pH 9.6). Plates were washed with PBST (0.05\% Tween in phosphate-buffered saline and blocked with $2 \%$ bovine serum albumin (Sigma) in PBST (PBSTA). Dilutions of each patient and control serum sample in PBSTA were added to the wells. Antigen concentrations and serum dilutions were judged as optimal by checkerboard titration. Bound antibodies were detected by incubation 
with peroxidase-conjugated antibody against human $\operatorname{IgG}(1 / 3000)$ (Sigma ), and enzyme-linked immunosorbent assay (ELISA) plates were developed as previously described Baxter,(2000). Blank samples without serum were included in quadruplicate on each plate. Optical density at $420 \mathrm{~nm}\left(\mathrm{OD}_{420}\right)$ was determined as described previously. An ELISA index was calculated by subtracting $\mathrm{OD}_{420}$ values of blank control samples from the values obtained with serum samples and by dividing the mean $\mathrm{OD}_{420}$ value for each sample by the mean $\mathrm{OD}_{420}$ values for a standard positive serum sample; these were determined in quadruplicate on each plate.

- SDS- PAGE activity assays. SDS - PAGE was carried out in $0.75 \mathrm{~mm}$ thick, $12 \%$ vertical slab gels ( E 64; Sigma ) according to the method described by HollmDelgado (2004). Equal protein content of bacterial extracts ( $50 \mu \mathrm{g} /$ lane ) was applied to the gel wells after mixing and boiling for $3 \mathrm{~min}$ with an equal volume of sample buffer [0.125 M trisma base , 4\% ( w /v ) SDS , 20\% ( v/v ) glycerol, $10 \%$ $(\mathrm{v} / \mathrm{v})$ mercaptoethanol and $0.1 \% \quad(\mathrm{w} / \mathrm{v})$ bromophenol blue as a tracking dye ]. A prestained molecular weight standard mixture [ $\beta$ - galactosidase Mw $117 \mathrm{Kda}$, fructose-6-phosphate kinase $\mathrm{Mw} 91.8 \mathrm{Kda}$,pyruvate kinase $\mathrm{Mw} 72.7 \mathrm{Kda}$, fumarase Mw 57.8 , lactic dehydrogenase $\mathrm{Mw} 40.8 \mathrm{Kda}$, and trio phosphate isomerase $\mathrm{Mw}$ $34.1 \mathrm{Kda}$, ] was prepared in parallel . Cleavage of IgG was determined by analyzing supernatant samples on $12 \%$ sodium dodecyl sulfate-polyacrylamide gel electrophoresis which was carried out with constant volt of $200 \mathrm{~V}$. Activity was determined by the presence of a diagnostic $31-\mathrm{kDa} \operatorname{IgG}$ cleavage product The run was terminated when the bromophenol blue marker reached to the bottom of the gel. The gel was silver stained according to the method described by Morrissey et al, (1986).

\section{A ) Bacterial stock :}

The used bacterium is the stock of Streptococcus pyogenes which secretes fusion protein directly into the medium, isolated and identified according to the instructions of Api (bioMerieux) National Committee for Clinical Laboratory Standard (NCCLS 1999).

B ) Production and Extraction of polysaccharide :

Takes of culture of Streptococcus pyogenes for centrifugation, the precipitation is washing for several times by distilled water and then for purification added an enzymatic treatment as trypsine ( $0.02 \%$ ).A volume of nine liters of culture, the weight of polysaccharide obtained $120 \mathrm{mg}$ extraction $\% 17.2$, the total of PSA / volume of culture was $13.3 \mathrm{mg}$. 


\section{Extaction by formamide :}

At $120{ }^{\circ} \mathrm{C}$ in water bath for $60 \mathrm{hrs}$ then we added acetone and then in resin ion exchange, we take the extract of polysaccharide of group A, the composition of polysaccharide and there percentage by extraction of formamide and purification are:

Rhamnose $(60 \%)$, where the chromatography indicates the absence of these amino acids: glucose amine(-), acetyl muramic acid(-), alanine(-),lysine(-), acetyl. glutamic acid(-) ,glycine(-) . To control the quality of PSA obtained we have effected the dosage of rhamnose which considered as a good indicator to the quantity of polysaccharide which considered as $60 \%$ for rhamnose extracted by formamide which liberate certain amino acids : 500ug of rhamnose in $0.5 \mathrm{mg} / \mathrm{ml}$ of aquous solution of polysaccharide of Streptococci of group A (PSA) then $0.5 \mathrm{ml}$ in a distilled water, an addition of sulfuric acid $4.5 \mathrm{ml}$ in a water bath for 10 minutes, after that we stopped the reaction with cold water, an aquous solution of $3 \%$ cysteine hydrochloride were added, we take $0.1 \mathrm{ml}$ with agitation, then we read the O.D at $415 \mathrm{~nm}$ by spectrophotometer .

\section{-The latex :}

The characteristic of preparation of latex uses : as Bacto - latex from Difco and the nature was PS ( polysterine ) with diameter 0.80 um and $5 \%$ solidity, function of surface $-\mathrm{COOH}$ being free. The resins were anion and cation exchange:

Make washing by distilled water then washing by methanol and then 3 times by distilled water, addition of $\mathrm{NaOH} 3 \mathrm{~N}$ as washing, then we repeat 3 times by distilled water and we added $\mathrm{Hcl} 3 \mathrm{~N}$ then 3 times daily of distilled water, then we take the stokage of resins in a distilled water at $4{ }^{\circ} \mathrm{C}$. The resins were purified before, than one $\mathrm{ml}$ of resin of anion exchange and $1 \mathrm{ml}$ of resin of cation exchange were mixed, addition of $0.5 \mathrm{ml}$ of latex and $5 \mathrm{ml}$ distilled water .

The suspension was mixed for 1 hour at room temperature. The latex was shown and stoked at $4{ }^{\circ} \mathrm{C}$, this will take place for fixing the antigen on the latex particles .

The conjugation of active polysaccharide plus the cyanuric chloride (2-4-6trichloro-1, 3, 5-triazine), ie.activates cellulose to immobilize DNA; gives a conjugate protein -polysaccharide. Series of plaques were being stoked at $4^{\circ} \mathrm{C}$ for 15 days O.D 415 and than the evolution of plaques was compared . 
Amino acids act as stabilizers used in the range $20-500 \mathrm{mM}$, amino acids and derivatives occur as osmolytes in nature. Sugars are being the best stabilizers but reducing sugars can react with protein amino groups leading to inactivation .

Gel filtration sample application: the technique was used for the detection of the polysaccharide antigen by using column chromatography packed by cation exchange resin, by means of the automatic analyzer 500 unit. Hundred ul of resin $1 \mathrm{mg} / \mathrm{ml}$ out of plug citrate of lithium $0.2 \mathrm{~N}$ is injected on the column. A S70, $150 \times 4 \times 0.1$ $\mathrm{mm}$, diameter $7 \mathrm{um}$. The elution was conducted by using different buffer solutions. The addition of ninhydrin can be used to detect the contaminated peptides or proteins, the proteins have been detected by electrophoresis on agarose gel. The duration of the separation was about 2-3 hrs.for developing patterns, the gel were washed with distilled water several times. Vlaminckx (1996).

\section{Conjugation of the poly-L-lysine:}

These methods used both the activation of polysaccharide by which take part and the remainder present between the polysaccharide and the protein.

\section{Results}

\section{Table 1}

The result indicate the good degree of purity of PSA product, to control the quality of PSA obtain, we effected the dosage of rhamnose as a good indicator for the quantity of polysaccharide.

A 1st phase in the extraction and purification, using column chromatography ( Fig.1)

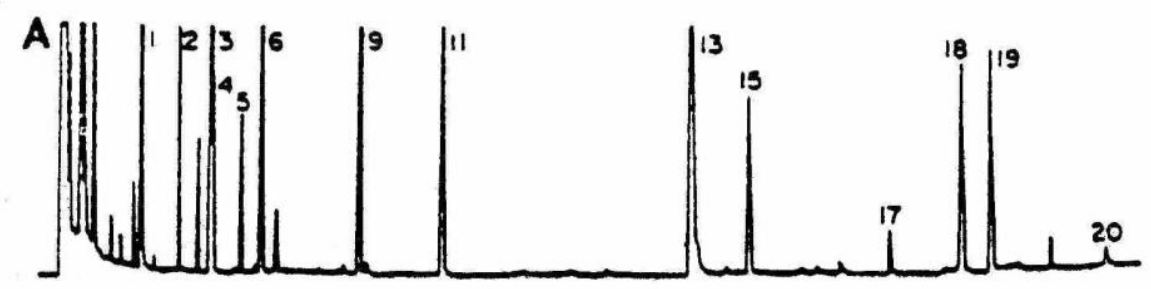

Rhamnose (1,3) N-acetylglucosamine ( 13,15,17,19) 
Table2: Reactivity of different polysaccharides by technique Elisa

\begin{tabular}{|l|l|l|l|l|}
\hline $\begin{array}{l}\text { Serum ( anti- } \\
\text { Streptococci })\end{array}$ & $\begin{array}{l}\text { OD of serums } \\
\text { Utilise }(*)\end{array}$ & PSA $(* *)$ & PSA- SBA & PSA-PLL \\
\hline A & 0.010 & 0.080 & 0.070 & 0.130 \\
\hline B & 0.100 & 0.120 & 0.110 & 0.195 \\
\hline C & 0.365 & 0.450 & 0.400 & 0.390 \\
\hline D & 0.365 & 0.706 & 0.700 & 0.695 \\
\hline E & 0.955 & 0.950 & 0.980 & 0.860 \\
\hline F & 1.100 & 1.060 & 1.010 & 1.125 \\
\hline
\end{tabular}

(*) serums of known optical density, determined by technique ELISA

(**) optical density of PSA polysaccharide of streptococci of group A purified. SBA serum bovine albumine PLL poly-L-lysine

After 5 min., we observe that the ppt. of PSA purified and the conjugation of PSA-SBA and PSA-PLL gives an identical antigenecity than the only one polysaccharide ; that means the immunological reactive is conserved . we find that the values with the PSA purified are identical with that known and obtained of the polysaccharide of reference The conjugation made it possible to find the values of optical density of serums used to fix the rate of proteins on latex, confirms that PSA-PLL ( $1 \mathrm{mg} / \mathrm{ml}$ of PSA ) remain fixed without loss of activity after 15 days of storage at $4{ }^{\circ} \mathrm{C}$ we observe a good stability of conjugation PSA-PLL than PSA-SBA during this work.

Table 3 : Result of normal adults

\begin{tabular}{|l|ll|l|l|l||l|l|l|l|l|l|}
\hline ELISA & \multicolumn{2}{|l|}{ ELISA } \\
\hline Serum & IgG & IgM & Latex & $\begin{array}{l}\text { Microa } \\
\text { gglu }\end{array}$ & $\begin{array}{l}\text { Hemag } \\
\text { glu }\end{array}$ & Serum & IgG & IgM & Latex & Microagg. & Hemagg \\
\hline 1 & 1.71 & 0.24 & 160 & 80 & 40 & 12 & 1.24 & 0.10 & 160 & 40 & 80 \\
2 & 0.72 & 0.33 & 80 & 40 & 80 & 13 & 0.82 & 0.10 & 160 & 80 & 160 \\
3 & 1.41 & 0.31 & 160 & 160 & 160 & 14 & 1.40 & 0.25 & 80 & 40 & 160 \\
4 & 1.52 & 0.24 & 160 & 80 & 160 & 15 & 1.83 & 0.27 & 320 & 160 & 160 \\
5 & 1.95 & 0.19 & 320 & 40 & 320 & 16 & 0.58 & 0.18 & 40 & 20 & 160 \\
6 & 1.75 & 0.11 & 640 & 320 & 320 & 17 & 0.25 & 0.45 & 80 & 80 & 80 \\
7 & 0.60 & 0.89 & 320 & 160 & 160 & 18 & 0.70 & 0.23 & 160 & 20 & 160 \\
8 & 1.24 & 0.23 & 80 & 80 & 80 & 19 & 0.91 & 0.15 & 160 & 80 & 80 \\
9 & 1.50 & 0.21 & 160 & 80 & 80 & 20 & 1.17 & 0.40 & 40 & 40 & 40 \\
10 & 1.09 & 0.11 & 80 & 80 & 160 & 21 & 0.80 & 0.00 & 80 & 40 & 80 \\
11 & 1.20 & 0.19 & 80 & 40 & 80 & 22 & 1.60 & 0.24 & 160 & 160 & 160 \\
\hline
\end{tabular}

Microagglu. $=$ Microagglutination Hemagglu $=$ Hemagglutination $\mathbf{N}$. of serum $=22$

The adult normal values for the technique of microagglutination \& heamahgglutination the +ve for technique ELISA, experm. values due to O.D for adults are 1.20 for IgM and 0.47 for $\mathrm{IgG}$. 
Table 4: results of normal child

\begin{tabular}{|c|c|c|c|c|}
\hline \multirow{2}{*}{ SERUMS } & \multicolumn{3}{|c|}{ ELISA } & \multirow{2}{*}{ LATEX } \\
\hline & $\mathrm{IgG}$ & IgM & IgT & \\
\hline 1. & 0.96 & 0.20 & 1.05 & 40 \\
\hline 2. & 0.42 & 0.13 & 0.49 & 10 \\
\hline 3. & 0.72 & 0.07 & 0.75 & 80 \\
\hline 4. & 0.53 & 0.19 & 0.55 & 20 \\
\hline 5. & 0.37 & 0.16 & 0.45 & 80 \\
\hline 6. & 0.15 & 0.07 & 1.15 & 80 \\
\hline 7. & 0.30 & 0.19 & 1.32 & 80 \\
\hline 8. & 0.24 & 0.50 & 1.40 & 160 \\
\hline 9. & 0.00 & 0.24 & 1.10 & 40 \\
\hline 10. & 0.20 & 0.40 & 1.30 & 80 \\
\hline 11. & 0.72 & 0.12 & 0.70 & 20 \\
\hline 12. & 0.34 & 0.10 & 0.35 & 40 \\
\hline 13. & 0.27 & 0.12 & 0.30 & 20 \\
\hline 14. & 0.53 & 0.21 & 0.55 & 20 \\
\hline 15. & 0.18 & 0.21 & 0.25 & 10 \\
\hline 16. & 0.71 & 0.18 & 0.80 & 80 \\
\hline 17. & 0.30 & 0.08 & 0.30 & 20 \\
\hline 18. & 0.21 & 0.35 & 0.35 & 80 \\
\hline 19. & 0.64 & 0.37 & 0.75 & 80 \\
\hline 20. & 0.54 & 0.25 & 0.60 & 40 \\
\hline 21. & 0.42 & 0.30 & 0.60 & 80 \\
\hline 22. & 0.27 & 0.47 & 0.45 & 80 \\
\hline 23. & 0.44 & 0.09 & 0.45 & 20 \\
\hline 24. & 0.21 & 0.86 & 0.85 & 160 \\
\hline
\end{tabular}

Children before 12 the values are 0.90 for $\operatorname{IgG}$ and 0.40 for $\operatorname{IgM}$. More than $60 \%$ $(n=40)$ of patients initially presented with skin or soft-tissue infections, and 27 of these met the criteria for NF.

Table5 : Children suspecting by Streptococci infection

\begin{tabular}{|r|r|r|r|r|}
\hline Serums & & Elisa & Latex & Time \\
\cline { 2 - 3 } & IgG & IgM & & 4 \\
\hline 1 & 1.45 & 0.75 & 1780 & 3 \\
\hline 2 & 0.10 & 0.30 & 80 & 3 \\
\hline 3 & 0.15 & 0.25 & 80 & 6 \\
\hline 4 & 1.50 & 0.15 & 320 & 5 \\
\hline 5 & 0.50 & 0.30 & 160 & 1 \\
\hline 6 & 0.15 & 0.20 & 20 & 5 \\
\hline 7 & 0.10 & 0.70 & 320 & 9 \\
\hline 8 & 0.40 & 0.25 & 20 & 13 \\
\hline 9 & 0.80 & 0.55 & 640 & 13 \\
\hline 10 & 0.20 & 0.35 & 160 & 17 \\
\hline 11 & 0.40 & 0.15 & 80 & 17 \\
\hline 12 & 1.25 & 0.20 & 160 & Pediatric \\
\hline 13 & 0.60 & 0.45 & 320 & \\
\hline
\end{tabular}


Table 6 : children suspecting by Streptococci infections of age group Hospital Abu el rich.

\begin{tabular}{|c|c|c|c|c|}
\hline H.Abu R & & \begin{tabular}{|l|} 
Microagglutination \\
\end{tabular} & Latex & Heamaglutination \\
\hline \multirow{4}{*}{ 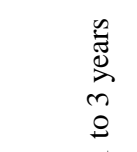 } & $\mathrm{N}$ (effective) & & 22 & \\
\hline & $\mathrm{X}$ (medium) & 92.73 & 374.55 & 83.18 \\
\hline & $\mathrm{T}$ (type) & 177.36 & 474.17 & 92.02 \\
\hline & $\mathrm{R}$ (coeff correlation) & 0.74 & & 0.86 \\
\hline \multirow{4}{*}{ 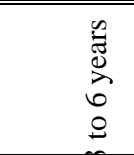 } & $\mathrm{N}$ (effective) & & 17 & \\
\hline & $\mathrm{X}$ (medium) & 168.24 & 523.53 & 260.00 \\
\hline & T (type) & 152.32 & 457.94 & 224.18 \\
\hline & $\mathrm{R}$ (coeff correlation) & 0.78 & $\mathrm{x}$ & 0.80 \\
\hline \multirow{4}{*}{ 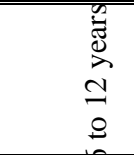 } & $\mathrm{N}$ (effective) & & 28 & \\
\hline & $\mathrm{X}$ (medium) & 130.71 & 621.79 & 260.00 \\
\hline & $\mathrm{T}$ (type) & 102.40 & 496.20 & 224.18 \\
\hline & $\mathrm{R}$ (coeff correlation) & 0.82 & $\mathrm{x}$ & 0.80 \\
\hline \multirow{4}{*}{$\begin{array}{l}\stackrel{0}{0} \\
\stackrel{0}{*}\end{array}$} & $\mathrm{~N}$ (effective) & & 17 & \\
\hline & $\mathrm{X}$ (medium) & 64.71 & 329.41 & 136.47 \\
\hline & T (type) & 31.81 & 191.85 & 93.11 \\
\hline & $\mathrm{R}$ (coeff correlation) & 0.44 & & 0.48 \\
\hline
\end{tabular}

H.Abu $\mathbf{R}=$ Hospital Abu el rich

Significant correlation with microagglutination and heamaglutination (1-3)

Significant correlation with microagglutination and heamaglutination (3 to 6)

Significant correlation with microagglutination and heamaglutination (6 to 12)

Non significant correlation with microagglutination and Sig.with heamaglutination (up to12)

Table 7 : Population atteind of acute rheumatic arthritis ( ARA ).

\begin{tabular}{|l|l|l|l|}
\hline & Microagglutination & Latex & Heamaglutination \\
\hline $\mathrm{N}($ effective $)$ & & 21 & $\star$ \\
\hline $\mathrm{X}($ medium $)$ & 172.86 & 519.05 & 423.81 \\
\hline $\mathrm{T}($ type $)$ & 171.94 & 367.88 & 279.16 \\
\hline $\mathrm{R}$ (coeff correlation & 0.19 & $\mathrm{x}$ & 0.78 \\
\hline \hline $\mathrm{N}($ effective $)$ & & 16 & $* *$ \\
\hline $\mathrm{X}($ medium $)$ & 162.50 & 605.00 & 525.00 \\
\hline $\mathrm{T}($ type $)$ & 147.29 & 414.70 & 441.79 \\
\hline $\mathrm{R}($ coeff correlation & 0.75 & $\mathrm{x}$ & 0.96 \\
\hline $\mathrm{N}($ effective $)$ & & 25 & $* * *$ \\
\hline $\mathrm{X}($ medium $)$ & 246.80 & 696.40 & 588.80 \\
\hline $\mathrm{T}($ type $)$ & 283.56 & 466.43 & 363.37 \\
\hline $\mathrm{R}($ coeff correlation & 0.65 & $\mathrm{x}$ & 0.71 \\
\hline
\end{tabular}

* Non significant correlation with microagglutination, significant with heamaglutination

** Significant correlation with the 2 techniques. (without cardite)

*** Significant correlation with the 2 techniques. (with cardite) 
The reactive latex prepared is sensitive, specific and has been utilized for the proportioning of the polysaccharide antibodies of Streptococcus of group A, comparatively with the ELISA.

\section{Discussion}

The Streptococci infections remain an important problem of health in the world not only for the industrialize countries but also for the developed countries. The selected method was used as to be of costless in the used techniques, the use of enteric bacteria is not possible and the ability to obtain a purified antigen and also secretes fusion protein directly into the media. Abou El Enien (1999).

The extraction of polysaccharide by the method of Krause and MacCarty (1996) recently modified by using formamide, allowing to obtain polysaccharide in large quantity, without contaminant cellular substances after mechanical disintegration of the bacterial cell wall. The non reducing sugars can be recycled from buffers and is not a convenient food source for bacteria. The chromatographic and electrophoresis analyses reveal the absence of amino acids ( alanine, glutamic acid etc.) as a constitution of peptidoglycan, indicates a certain purity of the antigenic preparation. For qualitative control of the polysaccharide the proportion of rhamnose concentration which is the main constituent with glucosamine was studied Pollard (2000).

Rhamnose concentration obtained in the sample under study is $(48 \%)$, this concentration is close to that of the reference polysaccharide (45\%) and comparable with the values of the data reported which obtained ( $60 \%$ ) rhamnose.

$\boldsymbol{P S A}$ developed in 34\%, renal dysfunction developed in 55\%, hepatic dysfunction developed in $64 \%$, and coagulopathy developed in $69 \%$ of patients. A total of $56 \%$ of patients were treated with IV polyspecific IgG, $81 \%$ were intubated and placed on mechanical ventilation, and $21 \%$ required renal replacement therapy. The median durations of ICU and hospital stay were 5.3 days and 15.0 days, respectively. The overall mortality was $40 \%$. Mortality correlated directly with acute physiology and chronic health evaluation II score and the number of dysfunctional organs. Survivors were younger, had lower severity of illness scores, fewer dysfunctional organs, and were less likely to have shock or to receive treatment with vasopressors, mechanical ventilation, or pulmonary artery catheters. Kaul, (1999).

There was no association between the use of vancomycim , surgical intervention, or clindamycin, and survival. Variables independently associated with mortality on multivariable analysis were the presence of coagulopathy $(p=0.0005)$ and liver 
dysfunction ( $\mathrm{p}=0.0123)$. So , Patients with invasive PSA infection admitted to the ICU have a high mortality rate. In this group of patients, coagulopathy and liver failure were independently as sociated with mortality. We did not observe any association between the use of vancomycin, surgical intervention, or clindamycin, and survival Hollm-Delgado,

(2005). The presence of antipolysaccharide antibody $A$ in the serum of healthy children using the latex was very high (4 to 10 times superior) compared to the normal value of the old aged. On the other hand the rates of $\operatorname{Ig} G$ are inferior than the normal children less than 3 years. In adults suffering from acute rheumatoid arthritis latex are 3 to 4 times superior with the normal values. The proportion of the antibodies by Elisa give high values.The best coefficient of correlation between the two techniques are obtained with the $I g$.

Patients with invasive GAS disease were admitted to the ICU in one of the four hospitals. More than $60 \%(n=40)$ of patients initially presented with skin or softtissue infections, and 27 of these met the criteria for NF. APS was the second-mostcommon site of infection at presentation. Sixty-eight percent of patients had blood culture results positive for PSA, four of whom had no obvious source of infection. At presentation, approximately $50 \%$ of patients had a history of chronic disease, including coronary artery disease, congestive heart failure, and pulmonary, renal, or liver disease. Ben-Abraham, (2002) .

The technique of fixation of the PSA to be purified on particles latex, after reduction and deacetylation, polysaccharides couldn't be use for the development of reaction of agglutination to latex. The immunological absence of reaction with respect to serum Anti-Streptococci of group $A$ is a proof of important alteration of antigenecity The reported that polysaccharides has proteins by the action of Benzylazo-proteins. This solution act to fix a protein at the polysaccharide The relating to the coupling of polysaccharide $A$ had the albumin bovine serum $(\boldsymbol{A B S})$ by the intermediate of cyanogens bromide. The used of cyano- chloride fixed polysaccharides poly-L-lysine \{activates cellulose to immobilize DNA\}.

The optimization of the covalent attachment on latex to function has to mix $50 \mathrm{ul}$ of PSA-PLL. 20 ul PSA for the process of purification have been fixed at the end of 2 hours by carbodiimide concentration of $1 \mathrm{mg} / \mathrm{ml}$ of preparation by radioimmunological proportion with group $A$ variable. The present reaction failed to show reactivity to cross with polysaccharides of other groups Streptococci . Use of a specific lectine of N-acetyl-glucosamine represent well but the best sensitivity is obtained by the immunoenzymatic technique was used to detect antibodies up to 1 / 
256000 ppm., carbodiimide on particles latex containing carboxylic functional groups lead to obtain a specific, significant reaction which is stable, also with low dose for storage and prevention from contamination where the result indicate the supplementation of irradiated performance. Darenberg, (2003).

The results of the present studies have a reproductivity technique, whatever the factor which can affect it. The stability of the reaction was maintained for one period of the study has $4{ }^{\circ} \mathrm{C}$ and $37^{\circ} \mathrm{C}$ the action have been to be preserved for 4 weeks which is sensitive, specific and stability to use for proportion of antipolysaccharide antibodies of Streptococci of group A comparatively with the Elisa.

In general, at the time of reappearing of the rheumatic fever, the clono type is observed, indicating that the acquired immunity is to associate the persistence of the clone in children population it could be observe that the averages increase up to 6 years old, and down again up to 12 years old towards values close to the normal adult values for the techniques of microagglutination and heamagglutination . In the population having $\boldsymbol{R A A}$, values increase according to the cardiac attack. It is useful to compare agglutination latex with the two other techniques of agglutination using the red globules or the bacterial cell wall. The correlation between the techniques latex and heamagglutination is well in all cases; whereas between the microagglutination and agglutination latex isn't significant in the children of less than 12 years and in the cases of $\boldsymbol{R A A}$. The specificity of the persistence of the APSA among patients has been to be confirmed by studies, to detect a fall of rates of antibodies reached of RAA without cardiac . Mulla, ZD., (2002).

The presence of the antipolysaccharide antibodies A has been to be observed in nearly $85 \%$ of the cases understudy of RAA confirms the assumptions of the role of these antibodies in the cardiac complications. The conjugation of polysaccharide has a protein (ASB or PLL) to develop for obtaining reaction latex, also to polyestyrine plates for the proportion of the $\boldsymbol{A P S A}$ by Elisa technique. The adsorption of the polysaccharide antigen on the surface of the plates in the time course when it combines to PSA-PLL remain fixed without loss of activity after 15 days of storage at $4{ }^{\circ} \mathrm{C}$ and the protein coupled activated sepharose is usually more stable to denaturation than the protein in free solution , the choice of buffer solution depends on the properties of the particular coupled protein as storage . Basma, (1999).

These systems could be interesting and should make it possible to improve the period of conservation and storage for a marketing of test proportion of the APSA, vancomycin320 $\mu \mathrm{g}$ once daily and $640 \mu \mathrm{g}$ twice daily produced significantly greater 
improvements in $\mathrm{PC}_{20} \mathrm{FEV}_{1}$ compared with placebo on Day 1 (within 2.5 hours), and on Days 3 and 7 (all p<0.0001). On Day 3, both ciclesonide doses significantly reduced exhaled NO levels by $-17.7(\mathrm{p}<0.0001)$ and -15.4 parts per billion $(p<0.003)$ versus placebo, respectively. Significant reductions were maintained during the study with both ciclesonide doses $(\mathrm{p}<0.01)$. Sputum interleukin- $1 \alpha,-6,-8$ and -12 were significantly $(\mathrm{p} \leq 0.01$ ) inhibited by ciclesonide $640 \mu \mathrm{g}$ twice daily within 4 hours; effects were maintained during the study. Norrby-Teglund, (2005).

The data obtained from the previous studies indicate the possibility of using a simple technique in diagnostic acute rheumatic arthritis.

Acknowlegment : We sincere to Prof. Dr.Safaa nasr for their helpful and encouragement, also for Dr.Patricot and Dr. Patric Trolier for the experiment offer and help in the stockage of latex and antigen polysaccharide given and their helping for the difficult in any problem and giving the solution. Pasteur Institute Lyon France my gratitude for all of them.

\section{References}

1. Abou El Enein I.(1999). Characterization of biological properties of the factor of Streptococcus pyogenes J. Pharm.,

2. Agniswamy, J., B. Lei, J. M. Musser, and P. D. Sun. (2004). Insight of host immune evasion mediated by two variants of group A streptococcus Mac protein. J. Biol. Chem. 279:52789-52796.

3. Baxter, F, McChesney, J Severe Group A streptococcal infection and streptococcal toxic shock syndrome. Can J Anesth (2000);47,1129-1140 .

4. Basma, H, Norrby-Teglund, A, Guedez, Y, et al Risk factors in the pathogenesis of invasive group A streptococcal infections: role of protective humoral immunity. Infect Immun (1999) ;67,1871-1877.

5. Beall, B., R. Facklam, T. Hoenes, and B. Schwartz. (2002) Survey of emm gene sequences and T-antigen types from systemic Streptococcus pyogenes infection isolates collected in San Francisco,California; Atlanta, Georgia; and Connecticut in 1994 and 1995. J. Clin. Microbiol. 35:1231-1235.

6. Ben-Abraham, R, Keller, N, Vered, R, et al Invasive Group A streptococcal infections in a large tertiary center: epidemiology, characteristics and outcome. Infection (2002);30,8185

7. Cunningham, M. W. (2000). Pathogenesis of group A streptococcal infections. Clin. Microbiol. Rev.13:470-511.

8. Darenberg, J, Ihendyane, N, Sjolin, J, and the StreptIg Study Group.. et al Intravenous immunoglobulin $\mathrm{G}$ therapy in streptococcal toxic shock syndrome: a European randomized, double-blind, placebo-controlled trial. Clin Infect Dis (2003);37,333-340.

9. Facklam, R. F., D. R. Martin, M. Lovgren, D. R. Johnson, A. Efstratiou, T. A. Thompson, S. Gowan, P. Kriz, G. J. Tyrrell, E. Kaplan, and B. Beall. (2002). Extension of the 
Lancefield classification for group A streptococci by addition of 22 new M protein gene sequence types from clinical isolates: emm103 to emm124. Clin. Infect. Dis. 34:28-38 .

10. Hollm-Delgado, MG, Allard, R, Pilon, PA Invasive group A streptococcal infections, clinical manifestations and their predictors, Emerg Infect Dis( 2005);11,77.

11. Kaul, R, McGeer, A, Low, DE, et al Population-based surveillance for group A streptococcal necrotizing fasciitis: clinical features, prognostic indicators, and microbiologic analysis of seventy-seven cases. Am J Med (1999) .,18-24 .

12. Krause and MacCarty M. enslimane A., Veysseyre C. Rotta J.,Bellaton A. (1996)Streptococcal group A polysaccharide antibodies assayed by an Elisa determination of antibodies in rabbit : normal levels in man and comparison with levels in patients with rheumatic fever. Zbl. Bakt. Hyg ., , A 262 , 385-395 .

13. Lei, B., F. R. DeLeo, N. P. Hoe, M. R. Graham, S. M. Mackie, R. L. Cole, M. Liu, H. R. Hill, D. E. Low, M. J. Federle, J. R. Scott, and J. M. Musser. (2001). Evasion of human innate and acquired immunity by a bacterial homolog of CD11b that inhibits opsonophagocytosis. Nat. Med. 7:1298-1305 .

14. Lukomski, S., N. P. Hoe, I. Abdi, J. Rurangirwa, P. Kordari, M. Liu, S. J. Dou, G. G. Adams, and J. M. Musser.(2000). Nonpolar inactivation of the hypervariable streptococcal inhibitor of complement gene (sic) in serotype M1 Streptococcus pyogenes significantly decreases mouse mucosal colonization. Infect. Immun. 68:535-542.

15. Morrissey, J.H.(1986). Silver stain polyacrylamide gels . A modified procedure with enhanced uniform sensitivity. Anal. Biocheme.177: 307-310.

16. Mulla, ZD Invasive group A streptococcal disease and intensive care unit admissions. Intensive Care Med (2002);28,1822-1824

17. Norrby-Teglund, A., K. Pauksens, S. E. Holm, and M. Norgren. (1996). Relation between low capacity of human serum to inhibit streptococcal mitogens and serious manifestation of disease. J. Infect. Dis. 170:585-591.

18. Norrby-Teglund, A, Muller, MP, Mcgeer, A, et al Successful management of severe group A streptococcal soft tissue infections using an aggressive medical regimen including intravenous polyspecific immunoglobulin together with a conservative surgical approach. Scand J Infect Dis (2005);37,166-172 .

19. Pollard ,J.W. ( 2000) Gel electrophoresis of proteins , in method of molecular biology , vol. 32 : basic protein and peptidoglycan ( walker, J . M. ed.) Humana. Totowa, $\mathrm{Nj}$. pp. 73- 85 .

20. Sriprakash, K. S., J. Hartas, and A. White. (2002). Antibodies to streptococcal inhibitor of complement function and $\mathrm{M}$ peptides in a post-streptococcal glomerulonephritis endemic region of Australia. J. Med. Microbiol. 51:589-594 .

21. Vlaminckx, B, van Pelt, W, Schouls, L, et al Epidemiological features of invasive and noninvasive group A streptococcal disease in the Netherlands, .Eur J Clin Microbiol Infect Dis (2004);23,434-444 . 


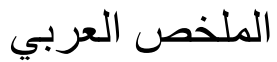

$$
\begin{aligned}
& \text { استخلاص و تنقية السكريات (عديدة الانتيجينيات) من الميكروب السبحي }
\end{aligned}
$$

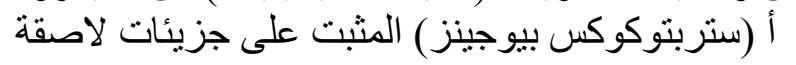

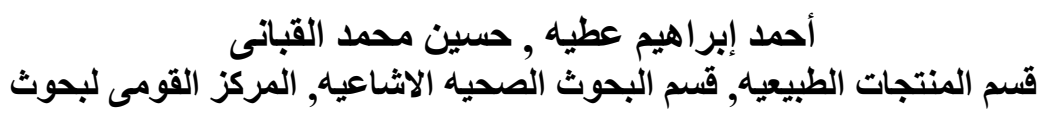

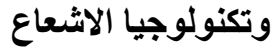

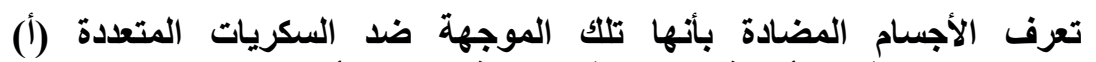

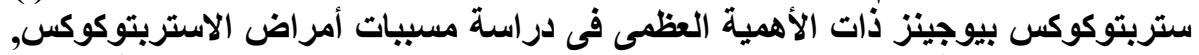

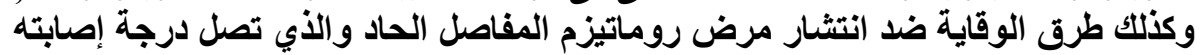
الغرض من البحث: لما انتشر هذا المرض فى البلدان النامية كان لزاما علينا نحن للقلب.

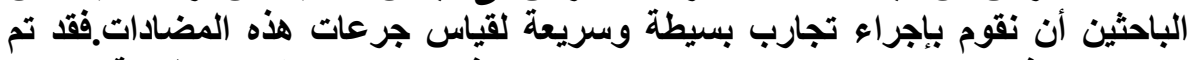

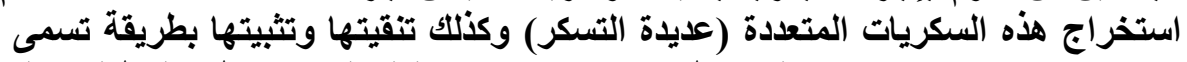
(Covalent coupling)

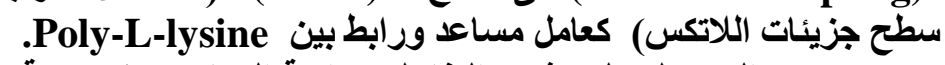

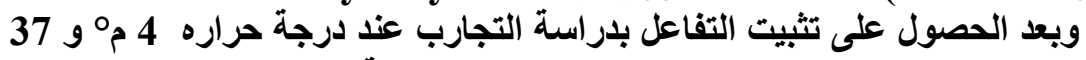

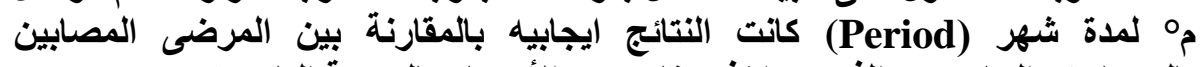

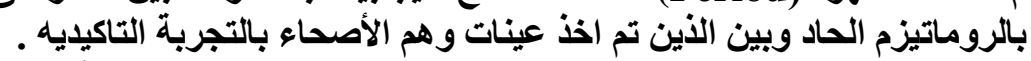

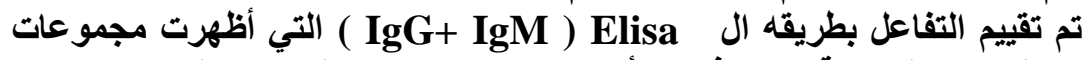

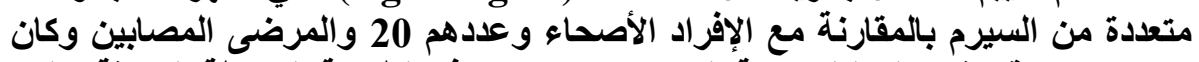

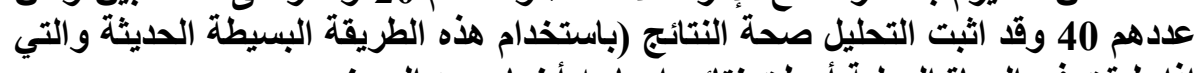

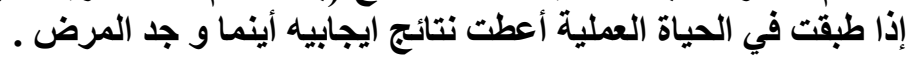

